\title{
Psychological Dependence on Social Media Usage of College Youth
}

\author{
G. Archana, P. Balaji
}

\begin{abstract}
The present study was exploratory and diagnostic in nature to examine the level of psychological dependence on social media networking sites usage of college youth in Chennai city of Tamil Nadu. This research was adopted survey method and structured questionnaire was collected from 200 college students residing in Chennai city to gather the information and perception on psychological dependence on social media networking sites addiction. The data collected were subjected to data analysis using PSPP software and statistical tools such as, percentage analysis, descriptive analysis and exploratory factor analysis to understand the level of social media addiction of college students. psychological dependence on social media networking sites variables have been reduced to Five independent factors and the most dominant factor is Communication Factor $(C F)$ followed by, Curiosity Factor (CUF), Attention Factor (AF), Time Factor (TM) and Upgradation Factor (UF) in their order of dominance.College youth are opined thatthey are more excited and curious to use a greater number of social media networking sites due to growth of internet and mobile penetration.To conclude, college youth can use social media networking sites with some limit timer through self-control and they should spend their quality time in the real world rather than the virtual world.
\end{abstract}

Keywords:Social Media, Networking Sites, Psychological Dependence, Curiosity, Attention and Social Interaction.

\section{INTRODUCTION}

The growth of technology paved a way for the growth of social media networking sites usage across the globe. The penetration in the smart phone usage and dependency of people towards technological platforms made them committed in social media networking sites. in addition to the internet addiction disorder and gaming addiction disorder, the social media addiction also causes many problems for the users. World health organisation announced that excessive social media usage as a psychological disorder among its users. Mental health, anxiety and depression are caused by social media networking sites across the people. especially, among the youngsters. There many youngsters and college students have shown the excessive intent and addiction to social media usage due to more time spent on social media. They feel more connected to the society by using the social media networking sites to get instant attraction and satisfaction and social attention in their society. There is a need to examine the social media addition behavior of college youth to drive them effectively towards healthy and effective social life.

Revised Manuscript Received on December 29, 2019.

* Correspondence Author

G. Archana, Ph.D. Research Scholar, Department of Commerce, VISTAS, Tamil Nadu, India. Email:archgovi3096@gmail.com

Dr. P. Balaji*, Assistant Professor, P.G and Research Department of Commerce, Guru Nanak College (Autonomous), Chennai, Tamil Nadu, India. Email: aravindbalaji23@gmail.com

\section{REVIEW OF LITERATURE}

Balaji and Sreenivasa Murthy (2019) conducted an exploratory study to made critical evaluation of social media networking sites of employed youth in Chennai city. The authors have adopted survey method to gather the data from employed youth from different form of industries. The result indicates that employed youth have excessive usage on social media networking sites and they prefer WhatsApp and Facebook to stay connected with society. The authors suggested to use social media platforms to create lucrative business ideas than wasting the valuable time in virtual world.

Andreassenet al., (2017) carried an exploratory study to explicit the relationship among social media addiction, self-esteem and vanity among Norwegians. The researcher has adopted Bergen Social Media Addiction Scale (BSMAS), the Narcissistic Personality Inventory-16, and the Rosenberg Self-Esteem Scales to investigate the behavioral addiction. The result indicates that females have more indent to use social media as compared to males and there is a cognitive strong relationship among self-esteem, vanity and social media usage of Norwegians.

Masthiet al., (2017) studied the comparison of social media addiction between government and private school students in Bengaluru city of Karnataka. The researchers have adopted cross sectional method of investigation and questionnaire method to carry the empirical study. The result indicates that private school students have more social media addiction as compared as Government school students in the study area.

Jaclyn Cabral (2008) examined the Generation Y behavior and addiction towards social media networking sites. The researcher has used Griffith's Six components to measure the social media addiction. This research was adopted questionnaire method to collect the perception and behavior of university students and result indicates that university students are suffers in tolerance, salience and relapse components in social media usage.

Imade Idubor (2015) investigated the social media addiction behavior among university students of Nigeria. The researcher has adopted carried an empirical and exploratory research from under-graduate students of University of Ibadan, Nigeria. The result indicates that social media usage and addiction are highly correlated to each other and Facebook and Twitter are the major social media networking sites preferred by respondents. Further, the author suggested to have orientation and awareness program for under-graduates' 
students for effective usage of social media to improve their academic performance.

\section{STATEMENT OF THE PROBLEM}

Social media usage has become a psychological dependency for today's college youth due to lack of knowledge and interest spend their quality time in real world. There is a excessive usage and higher time spending among youth due to the growth of mobile phone and internet industry in India. There is a need to examine the tendency and psychological dependency of college youth towards different social media networking sites such as, WhatsApp, Facebook, YouTube, Instagram, Twitter and LinkedIn in their daily life. This study aims to answer and investigate the psychological dependency of college youth towards social media networking sites.

\section{RESEARCH OBJECTIVES}

1. To understand the socio-economic background of the college students in Chennai city of Tamil Nadu.

2. To explore the dimensions of psychological dependence on social media networking sites usage of College students

\section{RESEARCH METHODOLOGY AND QUESTIONNAIRE DESIGN}

This research was adopted exploratory and empirical research design to conduct survey from 200 college students of Chennai city of Tamil Nadu with the help of structured questionnaire developed on psychological dependence of college students towards social media networking sites. The purposive sampling technique was adopted to gather the primary information and perception psychological dependence of college students towards social media networking sites in the study area. The structured questionnaire was designed with two sections namely, demographic profiles and psychological dependence on social media networking sites variables measured in the appropriate nominal and five-point Likert scales respectively.

\section{DATA ANALYSIS}

The data collected were subjected to analysis of data with the help of SPSS version 23.0 and the statistical tools such as, percentage analysis, descriptive analysis, mean based ranking and exploratory factor analysis has been applied to explore feasible solutions to the research problem of the study.

\section{RESULT AND DISCUSSION}

\section{A. Demographic profiles of the respondents:}

The demographic profiles of the respondent are majority of the respondents are males $(72.0 \%)$, hailing from nuclear family $(80.0 \%)$ and have monthly family income of less than Rs. $20,000(60.0 \%)$. All the respondents are single (100.0\%) and users of different social media networking sites (100.0\%) in their day-to-day life. Majority of the respondents are agreed that they may feel very difficult survive without Social media networking sites $(51.0 \%)$. Majority of the respondents have more than three types of social media accounts $(63.0 \%)$.

\section{B. Dimensions of Psychological dependence on social media networking sites Variables:}

The exploratory factor analysis has been applied for twenty-three psychological dependence on social media networking sites variables with Varimax rotation and Principle Component Method (PCA) of factorization. The results are tabulated and presented in Table 1 and Table 2.

Table 1: Descriptive Statistics of Psychological Dependence on Social media networking Sites Variables

\begin{tabular}{|c|c|c|}
\hline $\begin{array}{c}\text { Psychological Dependence on Social media } \\
\text { networking Sites }\end{array}$ & Mean & $\begin{array}{c}\text { Std. } \\
\text { Deviation }\end{array}$ \\
\hline I am eager to use social media & 3.290 & 1.257 \\
\hline $\begin{array}{l}\text { I look for internet connectivity everywhere to } \\
\text { go on social media }\end{array}$ & 2.890 & 1.408 \\
\hline $\begin{array}{l}\text { Looking social media is the first thing I do } \\
\text { when wake up in the morning }\end{array}$ & 2.960 & 1.480 \\
\hline I feel social media an escape from the world & 2.570 & 1.326 \\
\hline $\begin{array}{l}\text { A Life without social media becomes } \\
\text { meaningless for me }\end{array}$ & 2.070 & 1.265 \\
\hline $\begin{array}{l}\text { I Prefer to use social media even there are } \\
\text { somebody around me }\end{array}$ & 2.420 & 1.312 \\
\hline $\begin{array}{l}\text { I prefer friendship in social media rather than } \\
\text { in the real world }\end{array}$ & 1.660 & 1.118 \\
\hline $\begin{array}{l}7 * 0-I \text { express myself better to whom I meet } \\
\text { in the social media }\end{array}$ & 2.030 & 1.255 \\
\hline $\begin{array}{l}\text { I usually prefer to communicate people via } \\
\text { social media }\end{array}$ & 2.270 & 1.338 \\
\hline $\begin{array}{l}\text { I feel social media activities lay hold on my } \\
\text { everyday life }\end{array}$ & 2.580 & 1.215 \\
\hline $\begin{array}{l}\text { I miss out important activities due to time } \\
\text { spend on social media }\end{array}$ & 2.550 & 1.370 \\
\hline $\begin{array}{l}\text { I feel bad to decrease the time spend on social } \\
\text { media }\end{array}$ & 2.370 & 1.277 \\
\hline I feel unhappy when I am not on social media & 2.570 & 1.356 \\
\hline I feel exited to use social media & 3.100 & 1.319 \\
\hline $\begin{array}{l}\text { The mysterious world of social media always } \\
\text { capitates me }\end{array}$ & 2.460 & 1.292 \\
\hline $\begin{array}{l}\text { I do not even notice when I am thirsty while } \\
\text { on social media }\end{array}$ & 2.060 & 1.238 \\
\hline $\begin{array}{l}\text { I do not even notice when I am hungry while } \\
\text { on social media }\end{array}$ & 2.050 & 1.295 \\
\hline $\begin{array}{l}\text { I noticed that my productivity has diminished } \\
\text { due to social media usage }\end{array}$ & 2.770 & 1.267 \\
\hline $\begin{array}{l}\text { I have physical problems because of social } \\
\text { media usage }\end{array}$ & 2.310 & 1.400 \\
\hline $\begin{array}{l}\text { I use social media when I am walking on the } \\
\text { roads }\end{array}$ & 2.850 & 1.455 \\
\hline $\begin{array}{l}\text { I like to use social media to keep informed } \\
\text { about what happens }\end{array}$ & 3.590 & 1.285 \\
\hline $\begin{array}{l}\text { I have intended of sharing information in } \\
\text { social media groups }\end{array}$ & 3.190 & 1.273 \\
\hline $\begin{array}{l}\text { I active on social media to be instantly } \\
\text { informed about what my kith and kin share }\end{array}$ & 2.900 & 1.337 \\
\hline
\end{tabular}

Table 1 indicates that mean values for twenty-three psychological dependence on social media networking sites are robust in nature. Lower standard deviation values as compared to mean values reveals that data have normality. 
Table 2: Factorisation of Psychological Dependence on Social Media Networking Sites Variables

\begin{tabular}{|c|c|c|c|c|}
\hline $\begin{array}{l}\text { Factor } \\
\text { Label }\end{array}$ & $\begin{array}{c}\text { Psychological } \\
\text { Dependence on Social } \\
\text { Media Networking } \\
\text { Sites Variables }\end{array}$ & $\begin{array}{c}\text { Factor } \\
\text { Loadings }\end{array}$ & $\begin{array}{c}\% \text { of } \\
\text { Variance } \\
\text { Explained }\end{array}$ & $\begin{array}{l}\text { Reliability } \\
\text { Value }\end{array}$ \\
\hline \multirow{7}{*}{ 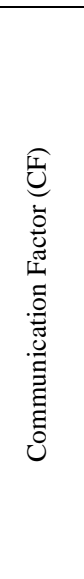 } & $\begin{array}{l}\text { I express myself better to } \\
\text { whom I meet in the social } \\
\text { media }\end{array}$ & 0.733 & \multirow{7}{*}{$\underset{n}{n}$} & \multirow{7}{*}{ స̃ } \\
\hline & $\begin{array}{l}\text { I usually prefer to } \\
\text { communicate people via } \\
\text { social media }\end{array}$ & 0.719 & & \\
\hline & $\begin{array}{l}\text { I Prefer to use social } \\
\text { media even there are } \\
\text { somebody around me }\end{array}$ & 0.636 & & \\
\hline & $\begin{array}{l}\text { I prefer friendship in } \\
\text { social media rather than } \\
\text { in the real world }\end{array}$ & 0.604 & & \\
\hline & $\begin{array}{l}\text { A Life without social } \\
\text { media } \quad \text { becomes } \\
\text { meaningless for me }\end{array}$ & 0.597 & & \\
\hline & $\begin{array}{l}\text { The mysterious world of } \\
\text { social media always } \\
\text { capitates me }\end{array}$ & 0.494 & & \\
\hline & $\begin{array}{l}\text { I feel social media an } \\
\text { escape from the world }\end{array}$ & 0.443 & & \\
\hline \multirow{5}{*}{ 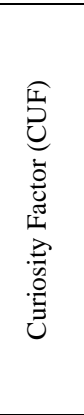 } & $\begin{array}{l}\text { I feel exited to use social } \\
\text { media }\end{array}$ & 0.754 & \multirow{5}{*}{$\frac{ \pm}{\stackrel{ \pm}{a}}$} & \multirow{5}{*}{$\begin{array}{l}\infty \\
\stackrel{\infty}{0} \\
0\end{array}$} \\
\hline & $\begin{array}{l}\text { I am eager to use social } \\
\text { media }\end{array}$ & 0.685 & & \\
\hline & $\begin{array}{l}\text { I look for internet } \\
\text { connectivity verywhere } \\
\text { to go on social media }\end{array}$ & 0.678 & & \\
\hline & $\begin{array}{l}\text { I feel unhappy when I am } \\
\text { not on social media }\end{array}$ & 0.528 & & \\
\hline & $\begin{array}{l}\text { I feel social media } \\
\text { activities lay hold on my } \\
\text { everyday life }\end{array}$ & 0.478 & & \\
\hline \multirow{2}{*}{ 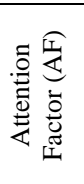 } & $\begin{array}{l}\text { I do not even notice when } \\
\text { I am thirsty while on } \\
\text { social media }\end{array}$ & 0.825 & \multirow{2}{*}{ 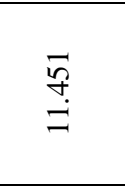 } & \multirow{2}{*}{$\frac{n}{\stackrel{+}{t}}$} \\
\hline & $\begin{array}{l}\text { I do not even notice when } \\
\text { I am hungry while on } \\
\text { social media }\end{array}$ & 0.814 & & \\
\hline \multirow{5}{*}{ 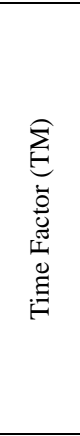 } & $\begin{array}{l}\text { I noticed that my } \\
\text { productivity } \\
\text { diminished due to social } \\
\text { media usage }\end{array}$ & 0.745 & \multirow{5}{*}{ î̊ } & \multirow{5}{*}{$\underset{\infty}{\infty}$} \\
\hline & $\begin{array}{l}\text { I miss out important } \\
\text { activities due to time } \\
\text { spend on social media }\end{array}$ & 0.739 & & \\
\hline & $\begin{array}{l}\text { I have physical problems } \\
\text { because of social media } \\
\text { usage }\end{array}$ & 0.688 & & \\
\hline & $\begin{array}{l}\text { I use social media when I } \\
\text { am walking on the roads }\end{array}$ & 0.513 & & \\
\hline & $\begin{array}{l}\text { I feel bad to decrease the } \\
\text { time spend on social } \\
\text { media }\end{array}$ & 0.422 & & \\
\hline \multirow{4}{*}{ 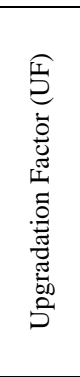 } & $\begin{array}{l}\text { I like to use social media } \\
\text { to keep informed about } \\
\text { what happens }\end{array}$ & 0.757 & \multirow{4}{*}{ ڤి } & \multirow{4}{*}{$\frac{\Omega}{\circ}$} \\
\hline & $\begin{array}{l}\text { I have intended of } \\
\text { sharing information in } \\
\text { social media groups }\end{array}$ & 0.752 & & \\
\hline & $\begin{array}{l}\text { I active on social media } \\
\text { to be instantly informed } \\
\text { about what my kith and } \\
\text { kin share }\end{array}$ & 0.553 & & \\
\hline & $\begin{array}{l}\text { Looking social media is } \\
\text { the first thing I do when } \\
\text { wake up in the morning }\end{array}$ & 0.408 & & \\
\hline \multicolumn{5}{|c|}{ 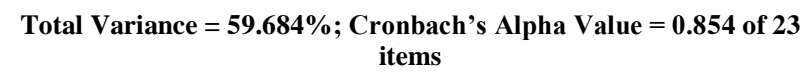 } \\
\hline \multicolumn{5}{|c|}{$\begin{array}{c}\text { Measure of Sampling Adequacy }=0.875 \\
\text { (Bartlett's Test of Sphericity Approx. Chi-Square: 1756.152; Df }= \\
\text { 253;P-Value }=<0.001)\end{array}$} \\
\hline
\end{tabular}

Tables 2 shows that KMO measure of Sampling Adequacy Value of 0.875 and Chi-Square value of 1756.152at degrees of freedom of 253 with P-Value of $<0.001$ in Barlett's Test of Sphericity proves that factor analysis can be applied for all the twenty-three psychological dependence on social media networking sites variables. Five factors have been extracted out of twenty-three variables and they explain $59.684 \%$ of the variance in the psychological dependence on social media networking sites variables. Thus, all the psychological dependence on social media networking sites variables have been reduced to Five independent factors and the most dominant factor is Communication Factor (CF) followed by, Curiosity Factor (CUF), Attention Factor (AF), Time Factor (TM) and Upgradation Factor (UF) in their order of dominance.

Table 3:

\section{Reversed Weighted Average Mean Ranking on Preference towards SNS's}

\begin{tabular}{|c|c|c|}
\hline $\begin{array}{c}\text { Social Media } \\
\text { Network sites }\end{array}$ & Mean & $\begin{array}{c}\text { Std. } \\
\text { Deviation }\end{array}$ \\
\hline Facebook & 2.80 & 1.565 \\
\hline Youtube & 4.14 & 0.960 \\
\hline Twitter & 2.17 & 1.464 \\
\hline Whatsapp & 4.41 & 0.792 \\
\hline Instagram & 3.68 & 1.532 \\
\hline Linkedin & 2.02 & 1.480 \\
\hline
\end{tabular}

Table 3 reveals that WhatsApp (Rank 1) is the most preferred social media networking site followed by YouTube (Rank 2), Instagram (Rank 3), Facebook (Rank 4), Twitter (Rank 5) and LinkedIn (Rank 6) in their order of preference among college youth.

\section{MANAGERIAL IMPLICATIONS AND CONCLUSION}

This empirical study proves that WhatsApp is the major social networking sites preferred by college youth which is primarily used to stay connected with the social environment. The college youth must spend useful time to build their professional networking social media sites rather than just a peer groups for social interaction. college youth uses social media networking sites to meet social partner in the social media, communicate and interact with somebody in their social network, to create a greater number of friends etc. They should give focus to real world rather than the virtual world where there is a meaningless interaction for life. They should spend quality time with their friends and family in the real world other than social media networking sites. Social media networks are always mysterious world used to escape from the real world.

Today's college youth are felt more excited and curious to use a greater number of social media networking sites due to growth of internet and mobile penetration. The parents should not encourage their children to spend more time on these electronic gadgets 
and they must encourage them to committed in any other aspects in the real world such as, sports, exercise and yoga to have peaceful mind and good physical and mental health in their day-to-day life. To conclude, college youth can use social media networking sites with some limit timer through self-control and they should spend their quality time in the real world rather than the virtual world.

\section{REFERENCES}

1. Andreassen, C. S., Pallesen, S., \& Griffiths, M. D. (2017). The relationship between addictive use of social media, narcissism, and self-esteem: Findings from a large national survey. Addictive behaviors, 64, 287-293.

2. Balaji, P., \& Murthy, S. S. Web 2.0: An Evaluation of Social Media Networking Sites.International Journal of Innovative Technology and Exploring Engineering (IJITEE). 8 (10). 752-759.

3. Cabral, J. (2008). Is generation Y addicted to social media. Future of children, 2(1), 5-14.

4. Idubor, I. (2015). Investigating social media usage and addiction levels among undergraduates in University of Ibadan, Nigeria. Journal of Education, Society and Behavioural Science, 291-301.

5. Masthi, N. N. R., Pruthvi, S., \& Mallekavu, P. (2017). A comparative study on social media addiction between public and private High School students of urban Bengaluru, India. Journal of Psychiatry, 18(2), 206-215.

\section{AUTHORS PROFILE}

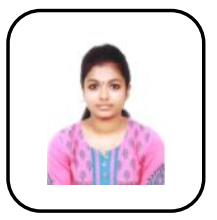

Ms. G. Archana, Ph.D. Research Scholar, Department of Commerce (General), VISTAS, Chennai. Her specialization for doctoral research is in the field of social media marketing and consumer behavior. She has received her Under-Graduation and Post-Graduation in Commerce from Stella maris college, Chennai. She has received Gold Medal for securing overall proficiency in post-graduation. She has cleared Tamil Nadu State- Level Eligibility Test in Commerce. Shewas contributed many empirical research articles to various eminent national and international level journals in the field of commerce and management indexed in SCOPUS/UGC CARE listed Journals and also actively participating in various national and international conferences.

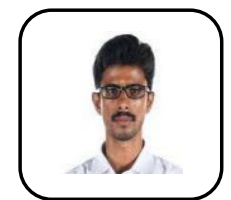

Dr. P. Balaji, Assistant Professor in Post Graduate and Research Department of Commerce, Guru Nanak College (Autonomous), Chennai. He has received Under-Graduation, Post-Graduation, Master of Philosophy and Doctor of Philosophy in Commerce from University of Madras, Chennai. He is the Life Member of Indian Commerce Association, Indian Accounting Association and Indian Finance Association. He has possessed four years of research experience and one-year teaching experience in the realm of commerce. He has cleared UGC NET and Tamil Nadu SET in the subject of Commerce. He was specialized in teaching related to Banking, Marketing and Human Resource Management and has research interest in the field of Banking Technology, Marketing Research and Human Resource Development. He was received three best paper awards in various international and national conferences. He is the recipient of Doctoral Research Fellowship from Institute of Public Enterprise, Hyderabad in collaboration with Indian Council of Social Science Research (ICSSR) for the doctoral thesis awarded from Department of Commerce, School of Business and Management Studies, University of Madras, Chennai. 